Aksaray University
Journal of Science and Engineering
e-ISSN: 2587-1277
http://dergipark.gov.tr/asujse
http://asujse.aksaray.edu.tr

Research Article

\title{
The Optimum Amount of Waste Glass Aggregate that can Substitute Fine Aggregate in Concrete
}

Aper E. Zava*, Samson N. Apebo, Paul T. Adeke

Department of Civil Engineering, University of Agriculture Makurdi, Nigeria.

-Received Date: Oct 09, 2020

-Accepted Date: Dec 28, 2020

-Published Online: Dec 28, 2020

\section{Abstract}

The study that is reported in this paper was carried out to study the effects of glass sand on the properties of concrete and determine the optimum amount of waste glass aggregate that can effectively replace fine aggregate in cement concrete. The objectives of the study were to prepare concrete specimens containing various amounts of glass sand as partial replacement for fine aggregate and to determine the properties of fresh and hardened concrete specimens so produced. It was found that glass sand does not have significant effect on the workability of concrete. The density of concrete containing glass sand was slightly lower than the density of normal concrete by a factor of $1-2 \%$. The presence of glass sand did not alter the established strength-time relation of concrete. The strength of concrete containing glass sand increased progressively with curing time. Glass sand had significant effect on the strength of concrete. A plot of concrete strength and glass sand content was a parabola curving downward. The peak strength, obtained at $10 \%$ glass sand content, was 1.2 times the target strength of $25 \mathrm{~N} / \mathrm{mm}^{2}$. The study concluded that the optimum amount of glass sand that can effectively substitute river sand in grade $\mathrm{C} 25$ concrete is $16 \%$ of the proportion of fine aggregate in the concrete. For plain concrete, glass sand alone can be used as fine aggregate. It was recommended that supplementary cementitious materials should be incorporated in the concrete to suppress the deleterious alkali-silica reaction that may take place when glass concrete is exposed to moisture.

\section{Keywords}

Alkali-silica reaction, Concrete, Fine aggregate, Glass sand, Recycling, Waste glass

*Corresponding Author:Aper E. Zava,E-mail: aperzava@gmail.com, $10000-0002-5745-7963$ 


\section{INTRODUCTION}

Post-consumer waste glass -which is generated after glass products are used and discarded by consumers- may result from a variety of sources, including municipal solid waste, industrial waste, construction and demolition waste, end-of-life vehicles, and waste from electric and electronics equipment [1]. Waste glass constitutes a significant chunk of municipal solid waste. A World Bank report written by Kaza et al. [2] revealed that the world generates about 2.01 Billion tons of municipal solid waste annually, $5 \%$ of which is waste glass. This means that the world generates about 100 Million tons of waste glass annually. In the year 2107, the USA was reported to have generated 11.4 Million tons of waste glass, representing $4.2 \%$ of all municipal solid waste that year [3]. In the UK, the Department of Environment, Food and Rural Affairs (DEFRA) [4] reported that the UK generated 2.4 Million tons of waste glass in the year 2017. It is stated in a publication of the German Federal Ministry of the Environment, Nature Conservation and Nuclear Safety [5] that 2.5 Million tons of waste glass was recovered from German household waste in 2015. Lu and Poon [6] reported that 100,000 tons of waste glass are generated in Hong Kong annually.

There have been concerted efforts in the developed world over the years to recover waste glass and use it as a raw material for making new glass containers, since doing so is the most environmentally friendly option. Yet, statistics on waste glass recycling rates available globally indicate that even the developed world throws away a significant chunk of the waste glass it generates, with the developing countries throwing away almost all of it. For instance, China recycles only $20 \%$ of the glass waste they generate [7]. In the USA, only $33 \%$ of waste glass gets recycled, the rest ends up in landfills [8]. The UK, on the other hand, was reported to have recycled as much as $67.6 \%$ of their waste glass in the year 2017[4]. European countries have been generally reported to be leading the world in waste glass recycling. The American Chemical Society [8] reported that, on average, 90\% of waste glass is recycled in several European countries. But it is mainly container glass that gets recycled this much. Recycling rate for flat glass has been reported to be as low as $11 \%$ [7]. This is because flat glass and other forms of non-container waste glass are not suitable for glassmaking.

The rate of reuse of recycled glass for making new glass products has been so low because of the difficulties and disadvantages associated with its recycling process, such as lack of recovery facilities in many locations, high processing cost, poor quality of recycled glass due to presence of impurities [6, 7, 9-13]. For these reasons, a significant chunk of waste glass gets thrown away. Considering that glass is non-biodegradable, continuous accumulation of waste glass Aksaray J. Sci. Eng. 4:2 (2020) 159-171. 
entails increased demand for landfill space; hence the need to find alternative ways of reusing waste glass in order to stop it from ending up in dumpsites.

Large-scale utilization of waste glass in concrete works can stop the continuous accumulation of waste glass and, in turn, help reduce the demand on landfill space for disposing waste glass. Waste glass has been used as aggregate and as a supplementary cementitious material in concrete. When crushed to sand-like particles, similar to natural sand, waste glass exhibits properties of an aggregate material [6, 14]. This knowledge has prompted the use of waste glass in construction as an aggregate substitute in asphalt and cement concretes and as road base or fill material $[9,14]$ as well as for the production of concrete products such as masonry blocks, paving stones, and decorative architectural mortars [10, 14-16]. Research pertaining to the use of waste glass as concrete ingredient has been encouraged by the threat posed by continuous accumulation of waste glass and the realization that large-scale utilization of waste glass in concrete works will help prevent the dumping of waste glass.

Several investigators have reported success in using crushed waste glass to replace fine aggregate in concrete. However, there is no consensus on the amount of waste glass aggregate that can be added to replace fine aggregate to produce concrete with optimum performance. The study that is reported in this paper was carried out to study the effects of waste glass aggregate content on the properties of concrete and determine the optimum amount of waste glass aggregate that can effectively replace fine aggregate in cement concrete. The objectives of the study were to prepare concrete specimens containing various amounts of crushed waste glass as partial replacement for fine aggregate and to determine the properties of fresh and hardened concrete specimens so produced.

The significance of this study is that it contributes to encouraging large-scale utilization of waste glass as aggregate in concrete which will go a long way in reducing pressure on natural sand deposits as well as in mitigating the problem of glass waste disposal that is faced by municipalities across the globe.

\section{REVIEW OF LITERATURE}

Processed crushed waste glass is referred to as cullet. Waste glass that is crushed to sand-like particles intended for use as fine aggregate in concrete has been referred to by various sources as waste glass fine aggregate, or simply as glass sand. Waste glass aggregate has been used to replace both fine and coarse aggregates partially or wholly. In other applications, powdered waste glass has been used as a supplementary cementitious material to partially replace cement. 
Results of investigations in all these applications have generally returned waste glass aggregate as a promising alternative concrete ingredient. The properties of concrete containing glass sand as fine aggregate - such as slump, density, water absorption, compressive strength, etc - have been studied and reported by several researchers. However, the trend of the variation of these properties with the content of glass sand in the concrete reported by various investigators lacks consistency. For instance, Rabnawaz et al. [17] and Rajagopalan et al. [18] reported that the slump of concrete containing glass sand increased with the amount of glass sand in the concrete, while Olofinnade et al. [19] reported a contrary finding that slump values decreased with increase in glass sand content. The decrease in slump was attributed to the angular geometry of the particles of waste glass, which reduced the fluidity of the concrete mixture. Otunyo and Okechukwu [20] found that concrete slump increased as glass sand content was increased up to a replacement level of $35 \%$; further increase in glass sand content beyond $35 \%$ resulted to reduction in the concrete slump. However, Hongjian and Kiang [21] and Gerges et al. [22] reported that there was no clear change or trend on the concrete slump values due to addition of glass sand. This was attributed to the shape and the impervious nature of glass particles. The investigators explained that "although the sharper edge and more angular shape of glass sand would reduce the slump of concrete, its impermeable smooth surface may also cause poor cohesion with cement paste. These two opposing actions would simultaneously result in nonprominent change in slump" [21].

Concerning the compressive strength of concrete containing glass sand, these investigators again recommended different dosages of glass sand to be incorporated into concrete to achieve optimum compressive strength. Hongjian and Kiang [21] postulated that glass sand can be incorporated into concrete as fine aggregate up to $100 \%$ replacement ratio without any harmful effect on the concrete. This finding was corroborated by Gerges et al. [22]. However, Otunyo and Okechukwu [20] found that the compressive strength of concrete increased with the amount of glass sand up to $15 \%$ replacement level, beyond which the compressive strength reduced with further increase in glass sand content. Olofinnade et al. [19] reported a similar trend but observed a reduction in compressive strength only when glass sand was increased beyond $50 \%$ replacement ratio; they observed that while the strengths at $25 \%$ and $50 \%$ replacement ratios were both higher than that of the reference concrete, $25 \%$ glass sand replacement ratio produced the highest strength. In a similar investigation, Gautam et al. [23] found that glass sand content beyond $20 \%$ resulted to a decrease in compressive strength; they recommended $10 \%$ as the optimum replacement ratio for glass sand as fine aggregate. 
Notwithstanding the beneficial effects of glass aggregate on concrete properties, its use in concrete is also problematic. The problem derives from the phenomenon of alkali-silica reaction (ASR) which occurs in concrete mixtures containing glass aggregates [9, 24]. Investigators found that when glass aggregate are present in a concrete mixture the silica in glass aggregate reacts with the alkali in cement creating a gel that swells in the presence of moisture, thereby causing the concrete to deteriorate in the long run. However, there are a number of measures which can be employed to suppress the harmful effect of ASR, such measures include using low-alkali Portland cement, incorporating supplementary cementitious materials such as fly ash, pulverized fuel ash, silica fume, slag, metakaolin and glass powder [11, 25, 26]. These measures are recommended when glass aggregate are to be incorporate in a concrete.

\section{MATERIALS AND METHODS}

\subsection{Materials}

\section{Cement}

Portland limestone cement (Grade 42.5, manufactured by the Nigerian Dangote Cement Industry) was used as binder material. It was bought from the open market.

\section{Crushed granite}

Crushed granite was used as coarse aggregate. Maximum aggregate size was $10 \mathrm{~mm}$. The granite gravel had a specific gravity of 2.91 . The aggregate impact value was $28 \%$, which is well within the limiting values on mechanical properties of aggregates specified by BS 882 [27] for certain types of concretes.

\section{River sand}

River sand was used as fine aggregate. It was sourced from River Benue, which is the only source of natural sand for concrete works in the region. The specific gravity of the river sand was 2.76. The grading curve of the sand is presented in Fig. 1.

\section{Glass sand}

Glass sand was produced by crushing pieces of waste glass to sand-like particles. Waste glass was collected from workshops of glass-window makers in Makurdi metropolis. Flat glass is routinely used for window panels in Nigeria. There is hardly any building in Nigeria that does not have glass windows. For this reason, glass-window making is a flourishing trade in Nigeria. Glass-window makers' workshops are common and are scatted all over every town and city in Nigeria. Cutting glass sheets to size in the course of making windows usually gives rise to a lot of off-cuts, which are usually discarded as waste, most often indiscriminately. It was these off- 
cuts that were collected as waste glass and used for this study. The off-cuts were washed, dried in the air and crushed manually. The resulting pieces of glass were passed through a set of BS sieves with apertures ranging from $5 \mathrm{~mm}$ to $75 \mu \mathrm{m}$, as recommended by BS 882 [27]. Glass particles that passed through the $5 \mathrm{~mm}$ sieve and retained on the $75 \mu \mathrm{m}$ sieve were collected as glass sand. The glass sand so produced had a specific gravity of 2.56. Its grading curve is presented in Fig. 1, which indicates that the river sand and glass sand have similar gradation.



Figure 1. Grading curves of river sand glass sand

\subsection{Concrete Mixture proportions}

Concrete specimens were produced using a mix ratio of 1:2:4 (by volume) and water-cement ratio of 0.5 . The expected concrete characteristic strength was $25 \mathrm{~N} / \mathrm{mm}^{2}$. Seven different concrete mixtures were produced. The amount of cement, coarse aggregate and water were kept constant for all the mixtures. However, the fine aggregate (river sand) was replaced with glass sand at $5 \%, 10 \%, 15 \%, 20 \%, 30 \%$ and $40 \%$, by mass of total fine aggregate content. Another mixture was produced with $100 \%$ river sand as fine aggregate to serve as the reference concrete. The different mix ratios of the constituent materials are presented in Table 1.

\subsection{Fresh and Hardened Concrete Tests}

\section{Slump test}

Slump test was carried out on fresh concrete specimens containing different amounts of glass sand to determine the effect of glass sand on the workability of concrete. The test was carried out in accordance with the provisions of BS 1881 Part 102 [28].

Compressive strength test 
The compressive strength test was carried out on hardened concrete containing different amounts of glass sand to determine the effect of glass sand on the compressive strength of concrete. A total of Sixty Three (63) test cubes were prepared, nine (9) for every blend of river sand and glass sand. The test cubes were cured and tested at 7, 14, and 28 days. The compressive strength test was performed in accordance with the provisions of BS 1881 Part 116 [29]. The batch quantities for a set of Nine (9) test cubes are presented in Table 3.

Table 1. Batch Quantities for a set of 9 test cubes (in $\mathrm{kg}$ )

\begin{tabular}{llllllll}
\hline Specimen Number & $\mathbf{1}$ & $\mathbf{2}$ & $\mathbf{3}$ & $\mathbf{4}$ & $\mathbf{5}$ & $\mathbf{6}$ & $\mathbf{7}$ \\
\hline Cement & 14.4 & 14.4 & 14.4 & 14.4 & 14.4 & 14.4 & 14.4 \\
Coarse Aggregate & 53 & 53 & 53 & 53 & 53 & 53 & 53 \\
River Sand & 25.2 & 23.9 & 22.7 & 21.4 & 20.2 & 17.6 & 15.1 \\
Glass Sand & 0 & 1.3 & 2.5 & 3.8 & 5.0 & 7.6 & 10.1 \\
Water & 7.2 & 7.2 & 7.2 & 7.2 & 7.2 & 7.2 & 7.2 \\
\hline
\end{tabular}

\section{RESULTS AND DISCUSSION}

\subsection{Effect of Glass Sand on Workability}

Slump test was carried out on concrete specimens containing different amounts of glass sand in order to study the effect of the presence of glass sand on the workability of concrete. Fig. 2 shows the variation of slump with glass sand content. The difference between the slump of the reference concrete and the slumps of concrete specimens containing glass sand ranged from \pm 1 to $\pm 3 \mathrm{~mm}$. The variation in slump was insignificant and did not follow any trend. This shows that glass sand has no effect on the workability of concrete.

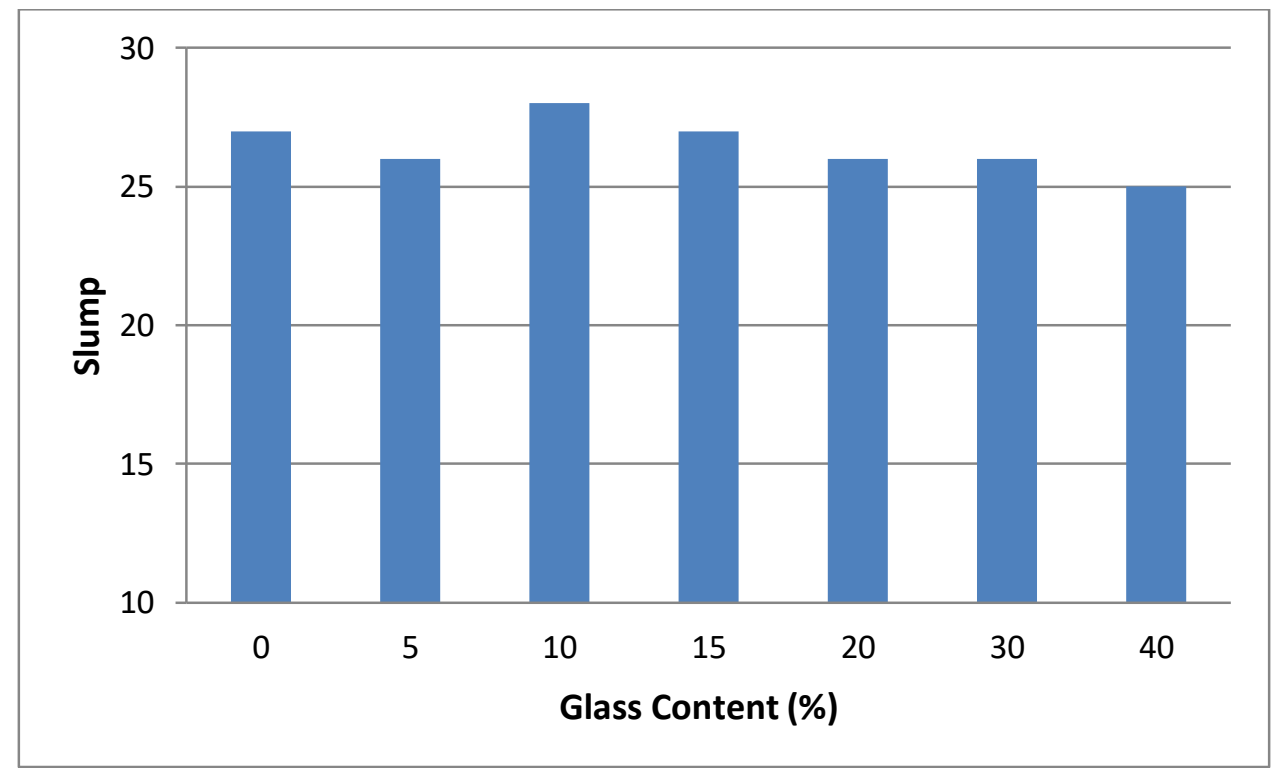

Figure 2. Variation of slump with glass sand content 


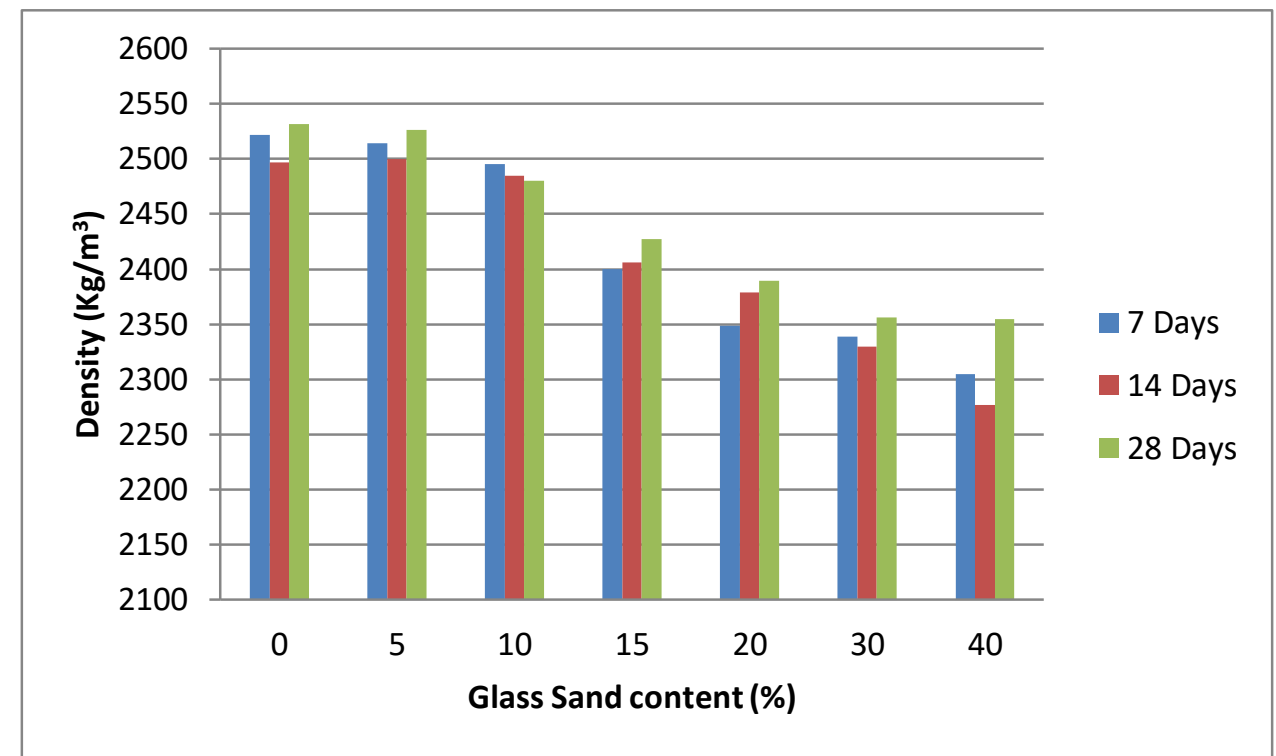

Figure 3. Variation of density of concrete with glass sand content

Workability of concrete is affected by the shape, texture and water-absorption characteristics of the aggregate. Domone [30] postulated that fresh concrete loses workability if mix water is absorbed by aggregate. Another factor that can cause concrete to lose workability is the presence of crushed aggregates with irregular angular shapes and rough surfaces [31-32]. It is evident, therefore, that the properties of glass sand have the effect of producing two opposing actions on the workability of concrete: the non-absorbent nature of glass has the effect of improving workability, while the irregular angular shape of glass particles has the effect of reducing workability. Mix water that was initially absorbed by the river sand was spared upon the incorporation of glass sand; this left the concrete wetter and hence more workable. However, the gain in workability produced by the rounded and smooth-textured river sand was diminished upon the incorporation of glass sand, which has more surface area and offered increased frictional resistance and hence loss of workability as a result of reduced fluidity of concrete mixture. These two opposing actions offered by glass sand on workability explain why the presence of glass sand in the concrete did not cause any significant change in the workability of the concrete.

\subsection{Effect of Glass Sand on Density}

It was observed from the density test that the presence of glass sand reduced the density of the concrete slightly. As it can be seen in Fig. 3, density decreased progressively with increase in glass sand content. However, the rate of decrement was quite small - about 1-2\%. The slight reduction in density can be attributed to the fact that glass sand has a specific gravity (2.56) that is slightly less than that of river sand (2.76). 


\subsection{Effect of Glass Sand on Compressive Strength}

Fig. 4 shows the variation of compressive strength with curing time, while Fig. 5 shows the variation of compressive strength with glass sand content. The strength of concrete containing glass sand increased progressively with curing time, with the highest strength obtained at 28 days for every replacement ratio. While the $28^{\text {th }}$ day strength of the reference concrete (without glass sand) was 1.2 times the $7^{\text {th }}$ day strength, the $28^{\text {th }}$ day strengths of all the concretes containing glass sand were greater than their corresponding $7^{\text {th }}$ day strength by an average factor of 1.3. This shows that glass sand has no significant effect on the already established strengthtime relation of concrete.

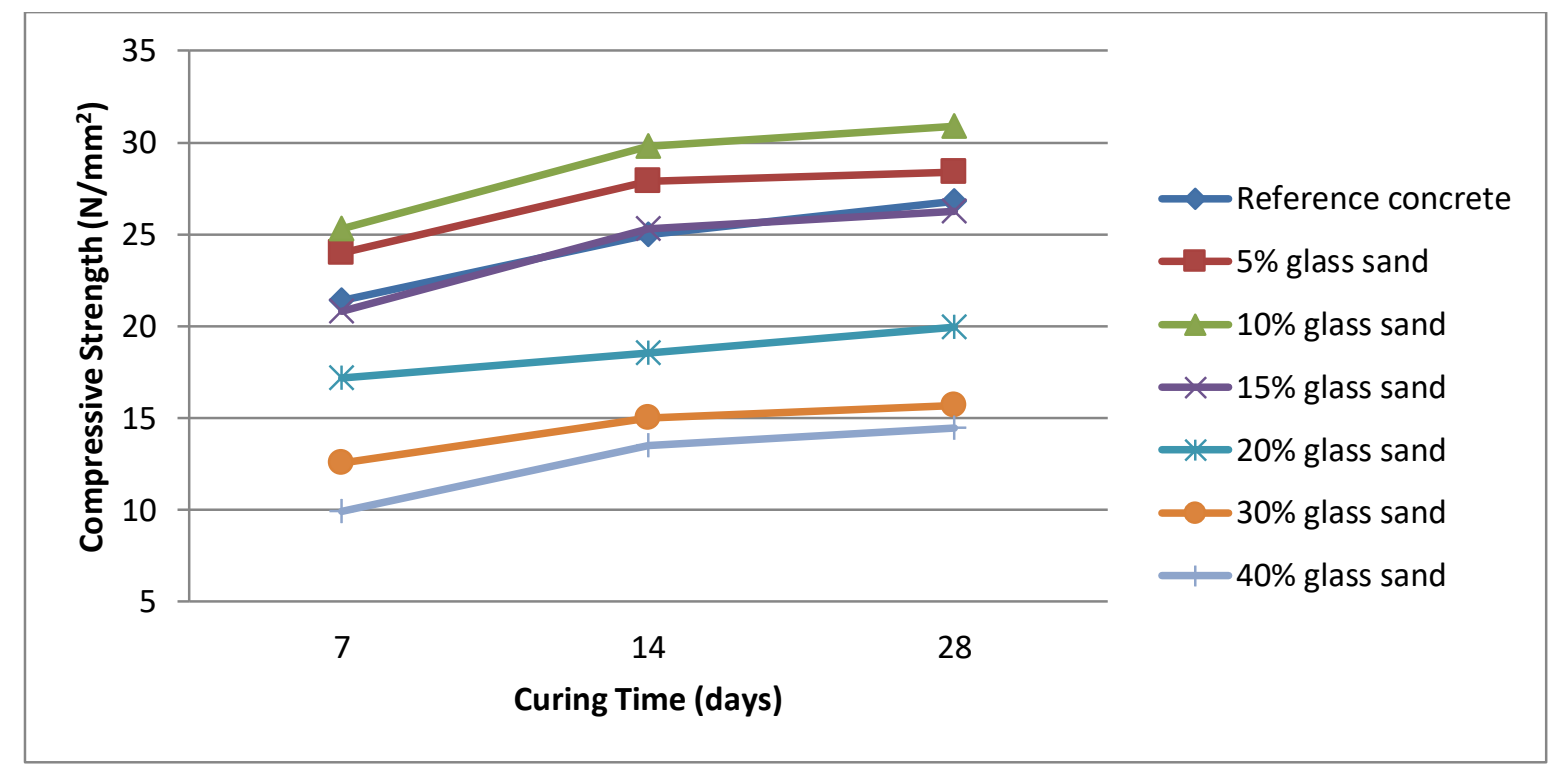

Figure 4. Gain of strength with time in concretes with different glass sand content

As it is evident in Fig. 5, the strength of concrete increased linearly with the amount of glass sand incorporated in the concrete between the replacement ratios of 5-15\%. Beyond this level, the strength of concrete started to decline with further increase in the amount of glass sand. 10\% replacement ratio produced the highest strength -1.2 times the target strength of $25 \mathrm{~N} / \mathrm{mm}^{2}$. This target strength was achieved at $16 \%$ replacement level. Therefore, the optimum amount of glass sand that can effectively replace river sand in grade C25 concrete is $16 \%$ of the proportion of fine aggregate in the concrete.

The initial increase in strength with glass sand content can be attributed to the increased bond strength between cement and aggregate due to the angular shape of glass sand particles and the silica that is present in glass and. The silica in glass sand reacted with the calcium hydroxide $\left(\mathrm{C}_{\mathrm{a}}(\mathrm{OH})_{2}\right)$ that is released from the hydration of cement, giving rise to additional calcium 
silicate hydrate (C-S-H), which contributes to the strength and volume stability of cement concrete. The strength loss that was observed at higher contents of glass sand can be attributed to the increased voids in the concrete. Olofinnade et al. [19] examined the microstructure of concrete containing glass sand using scanning electron microscope and found that the volume of voids in the concrete increased with increase in the content of glass sand.



Figure 5. Variation of compressive strength with glass sand content

\section{CONCLUSIONS}

Waste glass constitutes a significant chunk of municipal solid waste globally. The world generates about a hundred million tons of waste glass annually. Most of the waste glass generated globally gets discarded in landfills because of the problems associated with its recycling process. Large-scale utilization of waste glass in concrete works can help reduce the demand on landfill space posed by continuous accumulation of waste glass. The study was carried out to investigate the properties of concrete containing glass sand as fine aggregate with the aim of determining the optimum amount of glass sand that can effectively replace river sand as fine aggregate in concrete. The reference concrete was prepared using Portland cement, crushed granite and river sand, with target strength of $25 \mathrm{~N} / \mathrm{mm}^{2}$. Other concrete specimens were prepared using the same mix proportion as the reference concrete but with the river sand partially replaced with different amounts of glass sand. The study arrived at the following conclusions:

i. Waste glass is a promising concrete ingredient. It can be processed into glass sand (sandlike particles) and used as fine aggregate in concrete. 
ii. Glass sand does not have significant effect on the workability of concrete. The variations in the slumps of concrete specimens containing different amounts of glass sand were negligible and did not follow any trend.

iii. Glass sand has negligible effect on the density of concrete. The density of concrete containing glass sand was slightly lower than the density of normal concrete by a factor of $1-2 \%$.

iv. Glass sand has no significant effect on the already established strength-time relation of concrete. The strength of concrete containing glass sand increased progressively with curing time, with the highest strength obtained at 28 days for every replacement ratio.

v. Glass sand has significant effect on the strength of concrete. A plot of concrete strength and glass sand content was a parabola curving downward. The peak strength, obtained at $10 \%$ glass sand content, was 1.2 times the target strength of $25 \mathrm{~N} / \mathrm{m}^{2}$.

vi. The optimum amount of glass sand that can effectively substitute river sand in grade C25 concrete is $16 \%$ of the proportion of fine aggregate in the concrete.

vii. For plain concrete, glass sand alone can be used as fine aggregate.

\section{Recommendations}

Waste glass can be processed into sand-like particles and used as fine aggregate in concrete. However, supplementary cementitious materials should be incorporated to suppress the deleterious alkali-silica reaction that is likely to occur when glass concrete is exposed to moisture.

\section{Acknowledgement}

Acknowledgement is due to Emmanuel Apeh, a student of the Department of Civil Engineering, University of Agriculture Makurdi, Nigeria, who performed the laboratory experimental work that formed part of the study reported in this paper.

\section{REFERENCES}

[1] E.R. Vieitez, P. Eder, A. Villanueva, and H. Saveyn, End-of-Waste Criteria for Glass Cullet: Technical Proposal. Joint Research Center - Institute for Prospective Technological Studies Scientific and Technical Reports. EUR 25220 EN. European Commission. Luxemburg, (2011).

[2] S. Kaza, L. Yao, P. Bhada-Tata, F.V. Woerden, What a Waste 2.0: A global Snapshot of Solid Waste Management to 2050. World Bank, Washinton DC, Doi: 10.15961978-1-4648-1329-0. (2018).

[3] Environmental Protection Agency (EPA), Facts and Figures about Materials, Waste and Recycling. Retrieved from: epa.org/facts-and-figures-about-materials-waste-and-recycling/glass-materialspecific-data. (Accessed: 28 April 2020). 
[4] Department for Environment, Food and Rural Affairs (DEFRA). UK Statistics on Waste. Retrieved from:

https://assets.publishing.service.gov.uk/government/uploads/system/uploads/attachment_data/file/ $\underline{874265 / \text { uk Statistics On Waste statistical notice-March } 2020 \text { accessible Final rev v0.5.pdf. }}$ (Accessed: 18 June 2020).

[5] Federal Ministry for the Environment, Nature Conservation and Nuclear Safety, Waste Management in Germany 2018: Facts, data, diagrams, (2018). Retrieved from: www.bmu.de/en/publications. (Accessed: 18 June 2020).

[6] J.X. Lu and C.S. Poon, Recycling of Waste Glass in Construction Materials (Chapter 6), New Trends in Eco-efficient and Recycled Concrete, $1^{\text {st }}$ Edition, (2019) (pp. 153 - 167). Woodhead Publishing. Available online at: https://www.sciencedirect.com/topics/engineering/glass-aggregate

[7] J. Harder, Glass recycling - current market trends. Recovery Newsletter, (2018). Retrieved from: https://www.recovery-worldwide.com/en/artikel/glass-recycling-current-markettrends_3248774.html. (Accessed: 29 April 2020).

[8] American Chemical Society, Why Glass Recycling in the US is Broken, Chemical and Engineering News (C \& EN), 97(6), February 2019. Retrieved from: https://cen.acs.org/materials/inorganic_chemistry/glass-recycling-us-broken/97/i6. (Accessed: 28 April 2020).

[9] C. Meyer, N. Egosi, C. Andela, Concrete with Waste Glass as Aggregate in "Recycling and Re-use of Glass Cullet”, D., Dyer and Limbachiya, ed., Proceedings of the International Symposium Concrete Technology Unit of the ASCE and University of Dundee, March 19-20, 2001.

[10] W. Jin, C. Meyer, and S. Baxter, "Glasscrete"- Concrete with Glass Aggregate. ACI Materials Journal. 97(2) (2000) 208-213.

[11] K.P.E. Afshinnia, Waste Glass in Concrete has Advantages and Disadvantages, Concrete Decor, 19(8) (2019). Retrirved from: https://www.concretedecor.net/decorativeconcretearticles/vol-19no-8.november-december-2019/waste-glass-in-concrte-has-advantages-and-disadvantages/.

[12] Waste and Resources Action Program (WRAP), How are Glass Bottles Recycled? Retrieved from https://www.recyclenow.com/recycling-knowledge/how-is-it-recycled. (Accessed 18 June 2020).

[13] British Glass Manufacturers' Confederation, Recycling. Retrieved from https://www.britglass.org.uk/our-work/recycling. (Accessed 18 June 2020).

[14] Federal Highway Administration, User Guidelines for Waste and Byproduct Materials in Pavement Construction. Publication Number FHWA-RD-97-148. Retrieved from: fhwa.dot.gov/publications/research/infrastructure/structures/97148/wg1.cfm. (Accessed: 28 April 2020).

[15] R. Jain, L. Urban, H. Balbach, and M.D. Webb, Handbook of Environmental Engineering Assessment: Strategy, Planning, and Management. Chapter 12. $1^{\text {st }}$ Edition (2012). ButterworthHeinemann USA.

[16] F. Tittarelli, C. Giosue, A. Molali, Recycled Glass as Aggregate for Architectural Mortars. International Journal of Concrete Structures and Materials, 12 (2018) 57. 
[17] J. Rabnawaz, F.H. Wagan, and G.H. Wagan, Reuse of Glass in Concrete Analysis with minimizing Impact of Solid Waste on Environment. MOJ Civil Engineering, 4(3) (2018) 131-134.

[18] P. Rajagopalan, V. Balaji, N. Unnikrishnan, T. Jainulttag, and P. Bhuvaneshwari, Study on Bond Characteristics of Reinforced Waste Glass Aggregate Concrete,IOP Conf. Ser.: Earth \& Environ. Sci. 80 (2017) 012006.

[19] O.M. Olofinnade, A.N. Ede, J.M. Ndambuki, B.U. Ngene, I.I. Akinwumi, and O. Ofuyatan, Strength and Microstructure of Eco-concrete Produced Using Waste Glass as Partial Replacement for Sand. Cogent Engineering, 5(1) (2018) 1483860.

[20] A.W. Otunyo, B.N. Okechukwu, Performance of Concrete with Partial Replacement of Fine aggregate with crushed Waste Glass. Nigerian Journal of Technology (NIJOTECH). 36(2) (2017) 403-410.

[21] H. Du, K.H. Tan,Concrete with Recycled Glass as Fine Aggregate. ACI Materials Journal. 111(1) (2014) 47-58.

[22] N. Gerges, C. Issa, S. Fawaz, J. Jabbour, J. Jreige, A. Yacoub, Recycled Glass Concrete: Coarse and Fine Aggregates. European Journal of Engineering Research and Science, 3(1) (2018) 1-9.

[23] S.P. Gautam, V. Srivastava, and V.C. Agarwal, Use of Glass Waste as Fine Aggregate in Concrete. Journal of Academic and industrial Research, 1(6) (2012) 320-322.

[24] The Concrete Society Recycled glass aggregate. Retrieved from http://www.concrete.org.uk/fingertips-nuggets.asp? $\mathrm{cmd}=$ display\&id=783. (Accessed 4 October 2020).

[25] A. Anwar, TheInfluence of Waste Glass Powder as a Pozzolanic Material in Concrete. International Journal of Civil Engineering and Technology. 7(6) (2016) 131-148.

[26] D. Thompson, How to Use Glass as Aggregate in Concrete, Concrete Decor. 5(3), (2005). Retrieved from https://www.concretedecor.net/decorativeconcretearticles/vol-5-no-3-junejuly2005/mixtures-and-additives-using-glass-as-aggregate/

[27] BS 882, Specification for aggregates from natural sources for concrete, British Standard Institution, (1992). London. UK.

[28] BS 1881 Part 102, Testing Concrete. Method for Determination of Slump. British Standards Institution, (1983). London, UK.

[29] BS 1881 Part 116 Testing Concrete. Method for Determination of Compressive Strength of Concrete Cubes. British Standards Institution, (1983). London, UK.

[30] P.L. Domone, Fresh Concrete. In J. Newman and B.S. Choo (Eds.) Advanced Concrete Technology 2 - Concrete Properties, (Elsevier Ltd, Oxford, UK. 2003) pp. 1/3 - 1/29.

[31] J. Lay, The Effects of Natural Aggregates on the Properties of Concrete. In J. Newman and B.S. Choo (Eds.) Advanced Concrete Technology 1 - Constituent Materials, (Elsevier Ltd, Oxford, UK, 2003) pp. 8/1 - 8/16.

[32] G. Mishra, What are the Factors Affecting Workability of Concrete? The Constructor. Retrieved from https://theconstructor.org/concrte/factors-affecting-workability-concrete/11190/. (Accessed 20 June 2020)

Aksaray J. Sci. Eng. 4:2 (2020) 159-171. 